\author{
(online) $=$ ISSN $2285-3642$ \\ ISSN-L = $2285-3642$ \\ Journal of Economic Development, Environment and People \\ Volume 3, Issue 4, 2014 \\ URL: $\underline{\text { http://jedep.spiruharet.ro }}$ \\ e-mail: office jedep@spiruharet.ro
}

\title{
Including the monetary part in macro accounting: A 'modern' approach to the macroeconomic accounting ${ }^{a}$
}

\author{
Onur TUTULMAZ
}

Hitit University, Department of Economics

\begin{abstract}
Economic output is placed at the heart of the macroeconomics. To calculate the output one needs to achieve simplifying a high level complexity of economic relationships to form a system. On the flip side, the model should be enough elaborated to be able to reflect the important relationships. In this manner, the classical macroeconomic identity as Keynes suggested is simple enough to understand the main elements but it does not show the financial parts of transactions. Not having the monetary part of the economy it lacks the coherence. With the financial and economic crises getting more frequent, more endeavour to build a more inclusive and coherent macroeconomic system has been observed. However, there are large variety in different options of simplifying and simulating complex relationships among the real and monetary part of the modern economies. Our paper tries to set an analysis comparing some of the recent prominent ideas in building balance sheet and transaction flow matrix in regard to macroeconomic accounting system. We can conclude the new achievement of including the monetary transactions in the frame causes a compromise from the simplicity for a coherent and more complete picture of macro economy.
\end{abstract}

Keywords: Macroeconomic accounting; Transaction flow matrix; Output; Monetary economy; Macroeconomics.

JEL classification: E10, E42

\section{Introduction}

The development speed of the human economy has been fascinating in the last two centuries. Many times, the establishing the necessary institutions to evaluate and manage it follow behind of the developing economy and its changing structures ${ }^{1}$.

Money and the monetary institutions are one of the important parts of a modern economy. However, it has been long discussed that the monetary model we are applying to represent our economies and therefore its monetary theory is insufficient having important shortcomings in simulating the modern

\footnotetext{
${ }^{\mathrm{a}}$ The first version of this paper has been presented at ICESBA 2014 and published among the proceedings of the conference.

${ }^{1}$ For example, the Fed (Federal Reserves) in US was not established until 1913. Its independence has not been completed until 1951 (Moss, 2007, p.70; Moss and Brennan, 2002)
} 


\author{
(online) $=$ ISSN $2285-3642$ \\ ISSN-L = $2285-3642$ \\ Journal of Economic Development, Environment and People \\ Volume 3, Issue 4, 2014 \\ URL: http://jedep.spiruharet.ro \\ e-mail: office jedep@spiruharet.ro
}

economies. Wray (2012)'s suggestion, one of its several recent similar ones, of a "modern monetary theory" which combines the stock-flow consistent 3-sector balance approach of Godley (1996) and the modern money approach of Minsky (1986) and use it as a base for his monetary theory or, in better terms, modern interpretation of the macroeconomic modelling. Jackson and Dyson`s (2013) and Ryan-Collins et al. (2011) discuss also the issue within the same perspective. Godley and Lavoie's (2007) discussion on the issue that a better and more thorough method of macroeconomic accounting is possible and even necessary can be seen within the parallel direction.

National or macro level accounting of the economies are actually critically important to understand the structure of the economies and to better manage them. Godley and Lavoie introduce a more complete way of macro accounting and discuss how it better represents the economy.

In this paper we aim to elaborate this discussion analysing the mentioned approach of Godley and Lavoie. Comparing the recent developed methods with conventional macroeconomic methods and trying to underline important points that differ itself, the paper set a first look on the possible promises of such a more elaborate macro accounting system. Second chapter focuses on the macro accounting subject closer. Third chapter conducts a comparison between the approaches. Fourth chapter concludes the study.

\title{
2. Conventional Macro Accounts
}

The history of macro accounting is much younger than the development of the economy itself. In many aspects, however, it can be said that macro accounting of national income helped to improve economic modelling and to understand how it works.

Keynes defined the economic activity with the expenditure spent on the final activity. Equation 1 gives therefore the volume of an economy, in terms gross domestic products (GDP).

$C+I+G+N E x=Y$

Equation 1 has led to form a basic logic for a macro accounting system. Starting from 1930s the NIPA accounts ${ }^{2}$ are started to be measured according to the basic logic of overall expenditure.

Expenditures made on the total national product constitute, at the other end, the factor incomes, i.e. the disposable income plus net tax and transfers. Equation 2 gives this relationship as $W_{f}$ represents wages and factor incomes and $\mathrm{F}$ represents the profits. Taking account the disposable income definition, $Y_{d}=Y-T$, Equation 2 gives us the expenditure-income identity in a simplest manner (Equation 2 constitutes a base for transformation from expenditure matrix in Table 1 to income-expenditure matrix in Table 2):

$$
C+I+G+N E x=Y\left(=Y_{d}+T\right)=W_{f}+F+T
$$

Keynesian textbook expenditure identity given in Equation 1 and the first part of Equation 2 can be given in a matrix notation as in Table 1 below. In Table 1 we embark the double entry system which is used extensively by Godley and Lavoie (2007) for their balance sheet and transaction flow matrix analyses. The double entry system shows the direction of the transaction flows so that we can show transactions of the elements of basic macroeconomic identity. Here, the consumption expenditures made by the households

\footnotetext{
${ }^{2}$ Simon Kuznets from NBER (National Bureau of Economic Research) was appointed to build macro accounting system and the first estimates on national income was conducted in 1934 (BEA, 2006).
} 


\author{
(online) $=$ ISSN $2285-3642$ \\ ISSN-L = 2285 - 3642 \\ Journal of Economic Development, Environment and People \\ Volume 3, Issue 4, 2014
}

URL: http://jedep.spiruharet.ro

e-mail: office jedep@spiruharet.ro

are received by the firms for end products and services produced by the business. Government makes also spending the business production and services. The investment that the business achieves is financed by the private sector itself. The private sector here represents the financial private sector such as banks and other financial institutions.

Table 1. Matrix form of macroeconomic accounting on expenditures (closed economy from Eq. 1)

\begin{tabular}{|l|l|l|l|l|}
\hline & Households & Private sector & Private sector & Government \\
\hline Consumption & $-\mathrm{C}$ & $+\mathrm{C}$ & & \\
\hline Investment & & $+\mathrm{I}$ & $\mathrm{I}_{\mathrm{f}}$ & \\
\hline Government & & $+\mathrm{G}$ & & $-\mathrm{G}$ \\
\hline & & {$[\mathrm{Y}]$} & & \\
\hline
\end{tabular}

Setting double entry system we can see the flow directions in macroeconomic expenditure identity. However, the matrix form of the macroeconomic identity in Table 1 is not coherent. At this point we can try to introduce the income part of the identity in Equation 2. The wages and factor incomes are introduced a simplistic method in Table 2. Profits are classified as distributed $\left(F^{D}\right)$ and undistributed $\left(F^{U}\right)$. Distributed profits are channeled to the households and undistributed profits are capitalized by the firms. Factor incomes other than the profits are included in $\mathrm{W}$ and it is assumed that all the factor incomes are from the business to households. Tax $(T)$ is an income-decreasing factor for both business and households, forming the source of government expenditures. Tax is assumed here as net tax after substituting government transfers.

Table 2. Conventional income and expenditure matrix (closed economy from Eq. 2)

\begin{tabular}{|l|l|l|l|l|}
\hline & Households & Firms-Current & Firms-Capital & Government \\
\hline Consumption & $-\mathrm{C}$ & $+\mathrm{C}$ & & \\
\hline Investment & & $+\mathrm{I}$ & $-\mathrm{I}_{\mathrm{f}}$ & \\
\hline Government & & $+\mathrm{G}$ & & $-\mathrm{G}$ \\
\hline & & {$[\mathrm{Y}]$} & & \\
\hline Wages-factor inc. & $+\mathrm{W}$ & $-\mathrm{W}$ & & \\
\hline Net Profits & $+\mathrm{F}^{\mathrm{D}}$ & $-\mathrm{F}$ & $+\mathrm{F}^{U}$ & \\
\hline Tax and transfers & $-\mathrm{T}_{\mathrm{h}}$ & $-\mathrm{T}_{\mathrm{f}}$ & & $+\mathrm{T}$ \\
\hline
\end{tabular}

The expenditure matrix of Table 2 seems more inclusive in terms of the inclusion of factor income side of the income-expenditure identity. Therefore, we can see the identity coherence throughout the firmscurrent transactions: The summations of the expenditure elements determining the output is fully distributed to income items. Consequently, total expenditure is equaled to the total income throughout the business sector where the production of the end products and services take place. However, it lacks still the transaction coherence for all sectors. For example, the net savings of the sectors can be calculated here but where they are hold and by which financial tools are not known in Table 2. For that purpose, though, we need to build more inclusive system. We will see an attempt in this direction by Godley and Lavoie in the next section. 


\author{
(online) $=$ ISSN $2285-3642$ \\ ISSN-L = $2285-3642$ \\ Journal of Economic Development, Environment and People \\ Volume 3, Issue 4, 2014
}

URL: http://jedep.spiruharet.ro

e-mail: office jedep@spiruharet.ro

\title{
3. Income-Expenditure Matrix vs. Transaction Flow Matrix
}

\subsection{Transaction flow matrix}

Table 1.2 in the previous section, despite being useful to reflect the basic logic of measuring gross product of Equation 1 and Equation 2, cannot prevent some important questions to be raised. For example, we don't know about personal savings holdings; neither much about savings or deficits about business and government. In other words, which forms the savings falls in or deficits are financed from? A more complete accounting system takes the counterpart of the expenditures or the savings and configures the financial tools utilized. For example, the accounting system of the balance of budget does take in account the capital and the financial counterpart of the exchange of goods and services through the border. We know that the fund of transaction

In this manner, Table 3 gives more complete picture giving the flows of funds under the already known transactions from the NIPA system. According to different level of simplifying assumptions it is possible to build various different transaction flow matrixes. Following Godley and Lavoie (2007) we are giving detailed 5 sector transaction matrix. In Table 3, banks are placed separately to better cover especially financial and monetary transactions. Central bank is placed separately from government in a similar manner.

Table 3. Transactions flow matrix

\begin{tabular}{|c|c|c|c|c|c|c|c|c|c|}
\hline & House- & \multicolumn{2}{|c|}{ Production firms } & \multicolumn{2}{|c|}{ Banks } & \multirow[t]{2}{*}{ Government } & \multicolumn{2}{|c|}{ Central Bank } & \multirow{2}{*}{$\begin{array}{c}\Sigma \\
0\end{array}$} \\
\hline & & Current & Capital & Current & Capital & & Current & Capital & \\
\hline Consumption & $-\mathrm{C}$ & $+\mathrm{C}$ & & & & & & & 0 \\
\hline Investment & $-I_{h}$ & +1 & $-I_{f}$ & & & & & & 0 \\
\hline Government & & $+G$ & & & & $-G$ & & & 0 \\
\hline Wages & $+W B$ & $-W B$ & & & & & & & 0 \\
\hline Profits, firms & $+\mathrm{FD}_{\mathrm{f}}$ & $-\mathrm{F}_{\mathrm{t}}$ & $+\mathrm{FU}_{\mathrm{f}}$ & & & & & & 0 \\
\hline Profits, banks & $+\mathrm{FD}_{\mathrm{b}}$ & & & $-F_{b}$ & $+\mathrm{FU}_{\mathrm{b}}$ & & & & 0 \\
\hline Profits, Cent. B & & & & & & $+\mathrm{F}_{\mathrm{cb}}$ & $-\mathrm{F}_{\mathrm{cb}}$ & & 0 \\
\hline Loan interest & $-r_{\mid(-1)} \cdot L_{h(-1)}$ & $-r_{\mid(-1)} \cdot L_{f(-1)}$ & & $+r_{1(-1)} \cdot L_{(-1)}$ & & & & & 0 \\
\hline Deposit interest & $+r_{m(-1)} \cdot M_{h(-1)}$ & & & $-r_{m(-1)} \cdot M_{(-1)}$ & & & & & 0 \\
\hline Bill interest & $+r_{b(-1)} \cdot B_{h(-1)}$ & & & $+r_{b(-1)} \cdot B_{b(-1)}$ & & $-r_{b(-1)} \cdot B_{(-1)}$ & $+r_{b(-1)} \cdot B_{c b(-1)}$ & & 0 \\
\hline Taxes-Transfers & $-T_{h}$ & $-T_{f}$ & & $-T_{b}$ & & $+T$ & & & 0 \\
\hline$s u b-\Sigma$ & $S A V_{h}$ & 0 & $S A V_{b}=F U-I$ & 0 & $S A V_{b}=F U_{b}$ & $S A V_{g}=-D E F$ & 0 & 0 & \\
\hline Change in loans & $+\Delta \mathrm{L}_{\mathrm{h}}$ & & $+\Delta \mathrm{L}_{\mathrm{f}}$ & & $-\Delta \mathrm{L}$ & & & & 0 \\
\hline Change in cash & $-\Delta \mathrm{H}_{\mathrm{h}}$ & & & & $-\Delta \mathrm{H}_{\mathrm{b}}$ & & & $+\Delta \mathrm{H}$ & 0 \\
\hline Change, deposits & $-\Delta \mathrm{M}_{\mathrm{h}}$ & & & & $+\Delta \mathrm{M}_{\mathrm{b}}$ & & & & 0 \\
\hline Change in bills & $-\Delta \mathrm{B}_{\mathrm{h}}$ & & & & $-\Delta \mathrm{B}_{\mathrm{b}}$ & $+\Delta \mathrm{B}$ & & $-\Delta \mathrm{B}_{\mathrm{cb}}$ & 0 \\
\hline Change, equities & $\begin{array}{l}-\left(\Delta \mathrm{e}_{\mathrm{f}} \cdot \mathrm{p}_{\mathrm{ef}}\right. \\
\left.+\Delta \mathrm{e}_{\mathrm{b}} \cdot \mathrm{p}_{\mathrm{eb}}\right)\end{array}$ & & $+\Delta \mathrm{e}_{\mathrm{f}} \cdot \mathrm{p}_{\mathrm{ef}}$ & & $\begin{array}{l}+\Delta \mathrm{e}_{\mathrm{b}} \\
\mathrm{p}_{\mathrm{eb}}\end{array}$ & & & & 0 \\
\hline$\Sigma$ & 0 & 0 & 0 & 0 & 0 & 0 & 0 & 0 & 0 \\
\hline
\end{tabular}




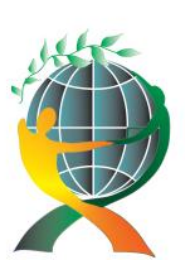

\author{
(online) $=$ ISSN $2285-3642$ \\ ISSN-L = $2285-3642$ \\ Journal of Economic Development, Environment and People \\ Volume 3, Issue 4, 2014 \\ URL: $\underline{\text { http://jedep.spiruharet.ro }}$ \\ e-mail: office jedep@spiruharet.ro
}

(Source: Godley and Lavoie, 2007, p.39; minor changes belong author)

The first part of the transaction flow matrix in Table 3, we can see the conventional NIPA accounts with the expenditures and the factor incomes of the sectors. Here the financial sectors are added to make it clear that where the funds are coming and where they are going. The central bank is also set separately. In Table 3 we can see the interest flows are given in detailed so we don't have to put the asset and liability interests together. Profits are divided into 2 groups; therefore, they are not just distributed to the households, some part of them stays undistributed and adds to the capital stock. We can see here investment expenditures take place in a more elaborate manner.

\title{
3.2. System Evaluation: NIPA vs. Transactional flow matrix
}

The macro accounting system tries to measure economic activity. An economic activity in a modern economy contains, at one side, the production of goods and services and exchange of them, often called real economy; it also contains, at the other side, also the monetary economy which does not just include the financial reflection of the real activity but also capsulate the pure monetary transactions consisting from the transactions among the financial tools. Therefore, a macro accounting system aiming to measure the economic activity should first be able to reflect the economy into a macro accounting model. As we know, a major modelling goal is to find the simplest model to represent the behaviour of the part of the universe that we interested, which is the economic activity here, In this manner, both conventional incomeexpenditure matrixes and the transaction flow matrixes have advantages and disadvantages.

First of all, a conventional income-expenditure matrix such as NIPA matrix helps to track the logic of GDP calculation. Expressing clearly the macroeconomic duality of the expenditure-income, it is also very helpful for pedagogical purposes. In other words, it is simple enough to represent the "real" part of the economy; so defined, it is useful to understand the real economy. However, it is uncertain that which financial tools are being used to finance these transactions, neither is the relationship between the financial tools and the real economy.

As for the transaction flow matrix, it can put the whole picture thoroughly. The first part of the transactional flow matrix given in Table 3 is same old income-expenditure matrix and reflects the 'real' part of the economy. The financial relations are given in detail in the below part of the matrix. Therefore we can see the all transactions including real and financial ones in the matrix and we can test their coherence. This constitutes a very important advantage because the causality in an economy is deemed to be bidirectional. Hence, the pure financial transactions to balance inter financial tools describing the interest rates have their effects into the real economy. That affecting mechanism generally deemed as via the interest rates. Interest rates are deemed to affect investment, consumption or foreign trade affecting the exchange rates.

\section{Conclusion}

The conventional macro accounting of an economy tries to capture the economic activity takes places in the 'real economy'. GDP numbers are produced through this macro accounting system, such as NIPA, and they are prevalently regarded as a measure of the economy. Even more importantly, accounting the macroeconomic activity in an economy we can show the way the economy runs and the roles of the different sectors in it. For example, it gives an opportunity to see and to check how the dual equality of macro incomes and expenditures works on a single table. 


\author{
(online) $=$ ISSN $2285-3642$ \\ ISSN-L = $2285-3642$ \\ Journal of Economic Development, Environment and People \\ Volume 3, Issue 4, 2014 \\ URL: http://jedep.spiruharet.ro \\ e-mail: office jedep@spiruharet.ro
}

We evaluate in this study, on the other hand, today's macro accounting system NIPA matrix is not totally coherent. If the balance of payments account, as a different macro accounting perspective of an economy, can supply this coherence in its calculations, it should be maintained for the macroeconomic accounts which are deemed to take a picture of the whole economy. For that purpose, it should include the financial and monetary dimensions of the running economy.

The most important point to be underlined is that the transaction flow matrix has such coherence for the whole of the economy. It has the financial transaction part as well as the conventional real economy part. The financial interdependencies can be followed as being in a sectorial balance sheet; while the coherence rule puts a reality check on them on sectorial base. Taking the bidirectional influences between the real and monetary part of the economy, the transactional matrix seems the sole system that can simulate the behaviour of the economy.

So far in the history the main focus was on the real part of the economy in terms of macro accounting systems, but in the modern world economy the monetary activity of an economy is much bigger than the real part. In addition to the monetary counterpart of the real exchanges, there are saving funds and also the pure monetary transactions following financial causes. The equilibrium reached through these financial transactions has its effects on real economy mainly via the interrelationship of interest rates with investment, consumption and exchange rates. Transaction flow matrix is the unique tool that one can see the all dimensions and their effects in a single accounting body. The literature shows that not only the practical application of such attempt but also the theoretical formation of one intact coherent macro accounting body is not easy at all. Therefore, we can conclude that further studies on the subject will be utmost useful both in economics theory and economic management on the field.

The last important point to make is that the having complete picture by fulfilling the total coherence of the transaction flow matrix is not the only important advantage of this new approach. But this total coherence is extremely important for the system dynamics point of view. Dealing with the complex systems as a modern economy, the system dynamics or the system thinking model can be effective the solve out the unexplainable or counter-intuitive fallacies in an modern economy such as our recent experiences of hedge fund crashes, bank crisis or market bubles.

\title{
References
}

[1] BEA (2006). A Guide to the National Income and Product Accounts of the United States. Available at: http://www.bea.gov/national/pdf/nipaguid.pdf.

[2] Godley, W. and Lavoie, M. (2007). Monetary Economics: An integrated approach to credit, money, income, production. Palgrave Macmillan, New York.

[3] Jackson, A. and Dyson, B. (2012). Modernising Money: Why our monetary system is broken and how it can be fixed, Positive Money, London, UK.

[4] Moss, D. (2002). A Concise Guide to Macroeconomics, Harvard Business School Press, Boston.

[5] Moss, D. and Brennan, S. (2002). National Economic Accounting: Past, Present and Future, Case 703-026, Harvard Business School Press, Boston.

[6] Ryan-Collins, J., L.R. (2012). Where Does Money Come From?Nef, London, UK.

[7] Wray, L.R. (2012). Modern Money Theory. Palgrave Macmillan, New York. 